\title{
CIBERCONSUMIDOR ATIVISTA E O DECRETO 7.962/13: ENCONTROS E DESENCONTROS NOS CRITÉRIOS DE AVALIAÇÃO DO CONSUMO VIRTUAL
}

\author{
Rafael Santos de Oliveira* \\ Mariana Fenalti Salla** \\ Jaqueline Bertoldo***
}

SUMÁRIO: Introdução; 2 Contrato Eletrônico e a Mudança do Paradigma Civilista; 3 Novas Formas de Proteção de Direitos: O Ciberativismo do Consumidor 2.0 e as Ferramentas de Avaliação das Relações de Consumo; 4 Contratos Eletrônicos: A Legislação em vigor no Brasil e sua Efetividade a partir da Análise dos Sites Selecionados; 5 Considerações Finais; Referências.

RESUMO: A popularizaçãodocomércioeletrôniconosúltimosanos, desacompanhada de uma evolução legislativa, acarretou muitas situações de desproteção do consumidor. Nesse contexto, foram criadas ferramentas virtuais que permitiam aos consumidores avaliarem as empresas e relatarem problemas, como E-bit. Somente no ano de 2013, foi editada uma norma (Decreto 7.962) que regulamentasse o comércio eletrônico. Todavia, questiona-se se os sites dos fornecedores melhor avaliados pelos consumidores na ferramenta E-bit correspondem aos sites que mais atendem às exigências da legislação. Assim, o presente trabalho objetiva identificar se as empresas mais bem avaliadas pelos consumidores na ferramenta de avaliação virtual correspondem àquelas que mais atentam às obrigações impostas pela legislação. O método de abordagem utilizado foi o dialético, método de procedimento comparativo e técnicas de pesquisa bibliográfica, documental e observatória participante. Conclui-se, ao final da análise, que os requisitos a serem cumpridos pela legislação não são os fatores determinantes para caracterização de uma empresa como boa pelo consumidor ativista.

PALAVRAS-CHAVE: Ciberconsumo; Consumidor 2.0; Contrato eletrônico; E-bit.

\footnotetext{
Doutor em Direito pela Universidade Federal de Santa Catarina (UFSC), Santa Catarina, Brasil; Docente do Programa de Pós-graduação em Direito da Universidade Federal de Santa Maria (UFSM), Rio Grande do Sul, Brasil; E-mail: advrso@gmail.com

* Pesquisadora do Centro de Estudos e Pesquisas em Direito e Internet (CEPEDI) da Universidade Federal de Santa Maria (UFSM), Rio Grande do Sul, Brasil.

${ }^{* * * *}$ Pesquisadora do Centro de Estudos e Pesquisas em Direito e Internet (CEPEDI) da Universidade Federal de Santa Maria (UFSM), Rio Grande do Sul, Brasil.
} 


\title{
ACTIVIST CYBERCONSUMER AND DECREE 7.962/2013: PROS AND CONTRAS OF THE EVALUATION CRITERIA OF VIRTUAL CONSUMPTION
}

\begin{abstract}
The popularization of electronic consumption during recent years without any evolution in legislation brought about several situations in which the consumer was left unguarded. Virtual tools were constructed so that consumer may assess firms and report issues, such as the E-bit. Although a norm was published in 2013 (Decree 7962) that regulated e-commerce, it may be asked whether the sites of the best evaluated suppliers in E-Bit tools are the sites that most attend to the requirements of the norm. Current paper identifies whether the best assessed firms by consumers correspond to those that attends the terms of the law. The dialectic approach, the comparative procedure method and bibliographical and documental research techniques coupled to observation were the methods employed. The requirements that must be observed by law are not the determining factors for the characterization of the firm as excellent from the point of view of the consumer.
\end{abstract}

KEY WORDS: Cyberconsumption; Eletronic contact; Consumer 2.0; E-bit.

\section{CIBERCONSUMIDOR ATIVISTA Y EL DECRETO 7.962/13: ENCUENTROS Y DESENCUENTROS EN LOS CRITERIOS DE EVALUACIÓN DEL CONSUMO VIRTUAL}

RESUMEN: La popularización del comercio electrónico en los últimos años, desacompañada de una evolución legislativa, ocasionó muchas situaciones de desprotección del consumidor. En ese contexto, fueron creadas herramientas virtuales que permitían a los consumidores evaluar las empresas y relatar problemas, como E-bit. Solo en 2013, fue editada una norma (Decreto 7.962) que reglamentó el comercio electrónico. Aún, se cuestiona si los sitios de los proveedores mejor evaluados por los consumidores en la herramienta E-bit corresponden a los sitios que mejor atienden a las exigencias de la legislación. Así, el presente trabajo objetiva identificar si las empresas mejor evaluadas por los consumidores en la herramienta virtual corresponden a aquellas que mejor cumplen las obligaciones impuestas por la legislación. El método de abordaje utilizado fue el dialéctico, método de procedimiento comparativo y técnicas de pesquisa bibliográfica, documental y observatorio participante. Se concluye, al final del análisis, que los requisitos a ser cumplidos por la legislación no son los factores determinantes para caracterización de una empresa como buena por el consumidor activista.

PALABRAS-CLAVE: Ciberconsumo; Consumo 2.0; Contrato electrónico, E-bit. 


\section{INTRODUÇÃO}

Ao longo dos tempos, a contratação sofreu grandes modificações. Os contratos, antes baseados na fidúcia e firmados pessoal e verbalmente, passaram a se despersonalizar e desmaterializar frente à massificação do consumo. A relação de igualdade entre os contratantes deu lugar a uma relação de consumo desequilibrada, em que o consumidor é hipossuficiente frente ao fornecedor. Consequentemente, a ampla liberdade negocial cedeu lugar à intervenção estatal nas relações negociais. Nesse contexto, a Constituição Federal de 1988 trouxe como um direito fundamental a proteção do consumidor. Para dar eficácia à previsão constitucional, em 1990 foi aprovado o Código de Defesa do Consumidor, o qual regulou amplamente essas relações.

Entretanto, as transformações nas práticas negociais são constantes e velozes e a assincronia com a morosidade do processo legislativo acarretam a rápida obsolescência da legislação. Nesse sentido, o surgimento e a popularização do comércio eletrônico nos últimos anos sem o acompanhamento de uma evolução legislativa acarretou muitas situações em que o consumidor se viu desprotegido frente a lesões sofridas. Como forma de autoproteção mútua, os consumidores começaram a praticar o ativismo digital, alertando uns aos outros de experiências ruins que teriam vivido com algumas empresas. Nesse contexto, foram criadas ferramentas virtuais que reuniam diversas avaliações de empresas feitas pelos consumidores.

Somente no ano de 2013 foi editada uma norma (Decreto 7.962) que regulamentou a contratação e o comércio eletrônico ${ }^{1}$. Todavia, questiona-se se os critérios considerados pelos consumidores ao avaliar uma empresa como boa ou ruim correspondem às exigências que a lei faz às mesmas.

Visando identificar alguma possível solução a esse questionamento, o presente trabalho analisa quatro fornecedores virtuais, avaliados pelos consumidores em ferramentas de ativismo digital com diferentes notas, verificando-se, em um segundo momento, se a legislação está sendo cumprida por eles² . Objetiva-se, ainda,

\footnotetext{
1 Os autores optaram pela utilização das expressões "contratos eletrônicos", "contratação eletrônica" e "comércio eletrônico" tendo em vista ser essa a terminologia adotada pelo Decreto 7.962/2013.

${ }^{2}$ Neste ponto, o presente trabalho objetiva verificar o quanto as empresas estão cumprindo as disposições do Decreto 7.962/2013 referentes à fase pré-contratual. Desse modo, será analisada a observância das determinações constantes nos artigos $2^{\circ}$, incisos I a VI; $4^{\circ}$, incisos I, II, V, VI, VII e parágrafo único; e $5^{\circ}$, caput. As disposições do artigo $3^{\circ}$ não foram verificadas por se referirem exclusivamente a páginas de compras coletivas, o que não foi objeto deste trabalho. Os itens analisados foram agrupados consoante sua proximidade temática em 12 quesitos.
} 
identificar se as empresas mais bem avaliadas pelos consumidores na ferramenta de avaliação virtual correspondem, ou não, àquelas que mais atendem ao cumprimento da legislação.

Assim, o presente trabalho foi realizado por meio do emprego do método de abordagem dialética, na medida em que se propõe a investigação da contratação eletrônica de modo dinâmico, buscando-se analisar as previsões legais em interação com a realidade dos consumidores ativistas no cenário consumerista. $\mathrm{O}$ método de procedimento adotado foi o comparativo, tendo em vista que as quatro páginas virtuais foram comparadas com a legislação, de modo a verificar adequações ou não à regra.

As técnicas de pesquisa utilizadas foram a bibliográfica, à medida que se estudou a doutrina acerca das temáticas abordadas no trabalho; documental, através da análise da legislação protetiva do consumidor; bem como observatória participante, vez que se assumiu a postura de consumidor virtual e simulou-se contratações eletrônicas para observar se os fornecedores estavam cumprindo as exigências legais.

Dentre as diversas ferramentas de avaliação de consumo existentes na Web, muitas delas apresentam seus rankings apenas pelo número total de reclamações, sem fazer uma análise da proporcionalidade entre o número de avaliações total da empresa e a porcentagem dessas que seriam negativas. Consequentemente, esses sites apresentam como mais bem avaliadas empresas menores, que raramente realizam contratações, logo, raramente recebem reclamações, e como pior avaliadas, grandes empresas, que realizam muitas contratações, tendo, por isso, uma quantidade de reclamações maiores.

Diversamente, a ferramenta E-bit solicita que os consumidores avaliem a experiência de compra em diversos aspectos, atribuindo-lhe uma nota de 1 a 5 logo após a contratação. A média das notas recebidas pela empresa lhe garantirá uma medalha, que poderá ser de bronze, prata, ouro ou diamante. Ao não classificar as empresas pela quantidade total de avaliações, mas pela média das notas recebidas, o E-bit revela-se uma ferramenta de avaliação mais justa no tratamento entre empresas de portes diferentes. Por essa razão, optou-se pelo uso da ferramenta E-bit neste trabalho.

Desse modo, foram escolhidas quatro lojas de um mesmo ramo de atuação (livros) para análise. Investigou-se na página E-bit quais eram as lojas de livros que 
estavam mais bem avaliadas dentro das medalhas diamante, ouro, prata e bronze. Essas quatro empresas foram selecionadas para a análise e doravante passam a ser denominadas Loja 1 (diamante), 2 (ouro), 3 (prata) e 4 (bronze) 3 .

O presente artigo foi dividido em quatro partes. Primeiramente, é feito um estudo bibliográfico acerca da evolução e publicização dos contratos, bem como sobre as novas formas de contratação eletrônica (1). Posteriormente, analisa-se o ciberativismo do consumidor 2.0 e as ferramentas de avaliação de consumo (2); ainda é realizado um estudo em relação à legislação protetiva do consumo virtual em vigor no Brasil (3). Por fim, apresentam-se os resultados da observação realizada nos sítios virtuais selecionados (4).

\section{CONTRATO ELERÔNICO E A MUDANÇA DO PARADIGMA CIVILISTA}

As práticas negociais fazem parte da vida do ser humano nas mais diversas formas de organização política e social. Conforme Roppo conceito jurídico que tem a finalidade de dar linguagem jurídica a todo arcabouço de regras e princípios que regem a disciplina complexa das operações econômicas 5 .

Ao longo do tempo, conforme a dinâmica e modelos sociais adotados, o contrato foi se modificando e, consequentemente, evoluindo. Fazendo um recorte histórico, pode-se citar a concepção clássica do contrato que foi delineada a partir das grandes codificações oitocentistas ${ }^{6}$, francesa e alemã, em que prevalecia a ideia

\footnotetext{
3 A investigação foi realizada em sua primeira vez no dia 11 de março de 2015 , sendo que a verificação foi repetida por diversas vezes dentro do mesmo mês, mantendo os resultados. À época, as lojas mais bem avaliadas dentro das medalhas diamante, ouro, prata e bronze foram, respectivamente, as empresas CNOVA Comércio Eletrônico S.A. (título do estabelecimento: Extra), Livraria Luana LTDA (título do estabelecimento: Livraria Luana), Editora Globo S.A. (título do estabelecimento: Editora Globo) e Alaúde Editorial LTDA (título do estabelecimento: Editora Alaude).

Como é natural, devido à classificação do E-bit basear-se na constante e diária avaliação dos consumidores, passado algum tempo, o resultado da classificação das empresas alterou-se. No entanto, pelo fato de a análise das páginas virtuais ter sido realizada concomitantemente à verificação das empresas mais bem classificadas, os resultados da pesquisa refletem os encontros e desencontros existentes entre a avaliação dos consumidores e o cumprimento dos requisitos exigidos pelo Decreto à mesma época, de modo que a pesquisa pôde atingir seus objetivos, sem que supervenientes alterações na classificação das empresas trouxessem prejuízos.

${ }^{4}$ ROPPO, E. O contrato. Coimbra: Almedina, 2009, p. 7-8.

5 Nesse sentido, Enzo Roppo afirma: "[...] o contrato, como formalização jurídica daquela (operação econômica), isto é conquista da ideia de que as operações económicas podem e devem ser reguladas pelo direito, e como construção da categoria científica idónea para tal fim; o direito dos contratos , como conjunto - historicamente mutável - das regras e dos princípios, de vez em quando escolhidos para conformar, duma certa maneira, aquele instituto jurídico [...]”. In: ROPPO, E. op. cit., p. 11.

${ }^{6}$ Os valores da nova sociedade do séc. XIX, surgida com as revoluções burguesas, traz à tona um novo modelo de contrato, baseado na igualdade formal entre os homens, que possuíam total liberdade para gerenciar suas relações negociais e troca de bens em antítese ao antigo regime absolutista, marcado ainda pelos privilégios corporativos e com economia fechada. In: ROPPO, E. op. cit., p. 28.
} 
de mínima intervenção do Estado nas relações negociais. Sob tal visão, Benjamin, Marques e Bessa ${ }^{7}$ apontam os princípios delineadores da teoria contratual tradicional: a) autonomia da vontade ou liberdade de contratar; b) força vinculante do contrato baseada no pacta sunt servanda; c) a relatividade dos efeitos contratuais.

Tal modelo logo foi dando sinais de esgotamento, visto que se mostrou insuficiente para responder às diversas situações da dinâmica contratual. Essa viragem acabou por exigir a passagem de um Estado mínimo para um Estado mais interventor, com decréscimo da antiga liberdade conquistada e revisão dos antigos princípios contratuais ${ }^{8}$. No Brasil, novas perspectivas para o campo negocial foram diretamente refletidas no texto constitucional, que indicou outro norte a ser seguido e reformulações ao direito privado.

Não demorou para que a evolução do tempo evidenciasse a necessidade dos princípios contratuais elaborados no século XIX. De um lado mais amplo, a passagem do Estado liberal para o social afetou diretamente a indiferença do poder público pela sorte dos contratantes. Assim, ao longo do século $\mathrm{XX}$, assistiu-se a inúmeras leis que impuseram limites à liberdade contratual (dirigismo contratual), ora definindo algumas regras mínimas, ora vedando expressamente determinadas cláusulas?.

Nesse sentido, surge o que passou a se chamar de publicização do direito privado, ou seja, a ação intervencionista do legislador para reduzir o espaço da autonomia privada de modo a garantir proteção aos vulneráveis e partes mais fracas ${ }^{10}$. Ademais, a constitucionalização do direito civil ou, nesse caso, do contrato, também toma forma nesse rol de mudanças, ou seja, o direito privado passa a ser iluminado diretamente pelas novas perspectivas surgidas com a Constituição de 1988, como a funcionalização dos direitos. Lima e Cambi ${ }^{11}$ explicam bem essa mudança de paradigma:

A importância do ordenamento jurídico privado, principalmente do Código Civil, é inegável, ele não perdeu seu espaço próprio, apenas torna-se mais solidário e ético, pois seus preceitos devem ser aplicados sob a óptica das normas constitucionais, estas entendidas como valores superiores que precisam ser observados tanto pelo Estado como pela sociedade nas suas relações.

No Código Civil, a nova visão afetou o direito dos contratos em diversos aspectos, dentre eles, Marques ${ }^{12}$ destaca a previsão da obrigatoriedade de que os contratantes

\footnotetext{
BENJAMIN, A. H. V.; MARQUES, C. L.; BESSA, L. R. Manual de Direito do Consumidor. São Paulo: Revista dos Tribunais, 2013, p. 352.

${ }^{8}$ LAWAND, J. J. Teoria Geral dos Contratos Eletrônicos. São Paulo: Juarez de Oliveira, 2013, p. 14-15.

9 BENJAMIN, A. H. V.; MARQUES, C. L.; BESSA, L. R. op. cit., p. 353.

${ }^{10}$ LÔBO, P. L. N. Constitucionalização do Direito Civil. Revista de Informação Legislativa, Brasília, v. 36, n. 141, jan./mar. 1999, p. 100.

${ }^{11}$ LIMA, J. N.; CAMBI, E. A. S. Os efeitos irradiantes da Constituição sobre o Direito Privado: seu processo de constitucionalização. Revista Jurídica Cesumar - Mestrado, v. 11, n. 2, jul./dez. 2011, p. 451-470.

${ }^{12}$ MARQUES, C. L. Diálogo entre o Código de Defesa do Consumidor e o novo Código Civil: do "Diálogo das Fontes" no combate às cláusulas abusivas. Revista de Direito do Consumidor, v. 45, ano 12, jan./mar. 2003, p. 93.
} 
guardem tanto na conclusão, quanto na execução os princípios da probidade e da boa fé, as normas sobre o controle e interpretação dos contratos de adesão, a previsão das cláusulas abusivas e da função social do contrato ${ }^{13}$. Assim, o contrato não mais possui o caráter absoluto tradicional, firmado na ideia de relatividade dos efeitos unicamente entre as parte e calcado na total liberdade para dispor de direitos e deveres.

Portanto, o direito subjetivo de contratar e a forma de seu exercício também são afetados pela funcionalização, que indica a atribuição de um poder tendo em vista certa finalidade ou a atribuição de um poder que se desdobra como dever, posto concedido para a satisfação de interesses não meramente próprios ou individuais, podendo também atingir a esfera dos interesses alheios ${ }^{14}$.

Martins-Costa ${ }^{15}$ ressalta que a norma contida no art. 421 é muito mais ampla que meramente uma restrição à liberdade contratual, ou seja, não é simplesmente uma "exceção" ao direito absoluto de contratar, mas sim integra o próprio conceito do contrato. "Há, portanto, um valor operativo, regulador da disciplina contratual, que deve ser utilizado não apenas na interpretação dos contratos, mas por igual, na integração e na concretização das normas contratuais particularmente consideradas".

A mudança mais visível no paradigma contratual está com a promulgação do Código de Defesa do Consumidor, que "vai, naturalmente, absorver as diretrizes constitucionais da solidariedade social e consagrar especial atenção ao vulnerável, com destaque para a proteção contratual"16.

Atualmente, com a difusão da Internet, as relações contratuais migraram com força para os espaços virtuais ${ }^{17}$, demandando novamente um processo de oxigenação e adaptação por parte da legislação para melhor regular e atender aos interesses dos contratantes, principalmente daqueles vulneráveis, facilmente identificados nesse ambiente. Desde as incipientes experiências com o uso da Internet, Lawand ${ }^{18}$ já trazia à tona as mudanças que ocorriam no mundo fático com relação às novas possibilidades de contratação pelos meios virtuais:

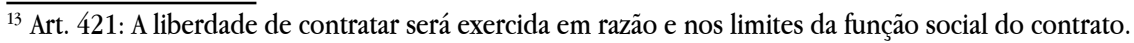

${ }^{14}$ MARTINS-COSTA, J.; BRANCO, G. L. C. Diretrizes Teóricas do Novo Código Civil Brasileiro. São Paulo: Saraiva, 2002, p. 158.

${ }^{15}$ Ibidem, p. 160.

${ }^{16}$ BENJAMIN, A. H. V.; MARQUES, C. L.; BESSA, L. R. op. cit., p. 355.

${ }^{17}$ Nesse sentido, cabe destacar a perspectiva apontada por Lawand: "[...] a tipologia contratual vem sofrendo atualizações constantes e evoluindo no sentido de acompanhar as novas tecnologias que vêm surgindo. Os contratos nascem das exigências cotidianas, especializando-se de acordo com as tendências pragmáticas, estão relacionados com a vida em sociedade, que diante de sua dinamicidade transforma-se frente às novas realidades sejam elas econômicas ou políticas". In: LAWAND, J. J. op. cit., p. 18.

${ }^{18}$ LAWAND, J. J. op. cit., p. 21-22.
} 
A revolução nos meios de comunicação, denominada de era do conhecimento, é a principal característica do final do século XX e início do século XXI. Passou-se a adotar um meio digitalizado, que implica no reconhecimento da internet como elemento onde é possível manifestar a vontade e as pessoas de lugares totalmente distintos têm acesso à comunicação de modo interativo, podendo encomendar e solicitar serviços e produtos, ou onde as empresas efetivam negócios com outras empresas fornecedoras e bancos, entre muitas outras facilidades.

Esta nova prática, que passou a ser denominada pela expressão "contrato eletrônico", é definida e diferenciada por Barbagalo ${ }^{19}$ como um encontro de vontades particulares, sendo que, nesse caso, as respectivas declarações acontecem por intermédio de computadores interligados entre si, para, desse modo, constituírem, modificarem ou extinguirem um determinado vínculo jurídico desejado.

Conforme a classificação dos contratos eletrônicos apresentada por Barbagalo, eles dividem-se entre contratos intersistêmicos ${ }^{20}$, contratos interpessoais $^{21}$ e contratos interativos, de acordo com o modo utilizado para a declaração de vontade das partes contratantes.

Os contratos interativos, objeto do presente estudo, são visualizados quando "uma pessoa interage com um sistema destinado ao processamento eletrônico de informações colocado à disposição por outra pessoa, sem que esta esteja, ao mesmo tempo, conectada e sem que tenha ciência imediata de que o contato foi efetuado"22. É a forma mais comum de contratação por meio da Internet, tendo sido amplamente popularizada no mercado das relações de consumo, facilitando ao consumidor a realização de suas compras, sem precisar sair de casa e com acesso a um rol muito maior de produtos e fornecedores.

Assim, também é a modalidade em que se verifica uma grade preocupação por parte do direito, visto que na grande maioria das vezes o perfil do contratante

${ }^{19}$ BARBAGALO, E. B. Contratos Eletrônicos. São Paulo: Saraiva, 2001, p. 37.

20 "São assim caracterizados os contratos eletrônicos formados utilizando-se o computador como ponto convergente de vontades preexistentes, ou seja, as partes apenas transpõem para o computador as vontades resultantes de negociação prévia. [...] Por esse modo, as partes contratam as regras que regerão as comunicações e transações a se realizar eletronicamente, tratando-se aqui de uma comunicação intersistêmica, na qual os sistemas de computador dos contratantes se interligam para a comunicação". BARBAGALO, E. B. op. cit., p. 51.

21 "Como interpessoais podem ser entendidos os contratos celebrados por computador quando este é utilizado como meio de comunicação entre as partes, interagindo na formação da vontade destas e na instrumentalização do contrato, não sendo apenas forma de comunicação de vontade já concebida. [...] Tais seriam, por exemplo, os contratos firmados por meio de ambientes de conversação, os chamados chats, ou os contratos que se firmam por intermédio de videoconferência”. BARBAGALO, E. B. op. cit., p. 53-54.

${ }^{22}$ Ibidem, p. 55. 
é de um consumidor vulnerável, sendo polo mais fraco da relação jurídica. Essa vulnerabilidade $^{23}$ se verifica claramente nessas relações, em função das novas especificidades ${ }^{24}$ presentes na contratação por meio da Internet.

Ao buscar realizar uma transação através da Web na forma do contrato interativo, o consumidor é exposto a uma infinidade de sites que oferecem seus produtos, geralmente com carências de informações, sendo que o adquirente não tem qualquer contato físico com o bem, restando unicamente confiar na descrição apresentada pelo fornecedor.

Conforme destaca Silva ${ }^{25}$, o consumidor

[...] fica sujeito a um modelo de contratação cuja dialética é substituída por operações como 'clicar' no produto, 'arrastá-lo' para a cesta de compras, 'informar dados pessoais' e inserir informações sobre forma de pagamento. A prática contratual não favorece o esclarecimento de eventuais dúvidas que o adquirente possa ainda manter após ler as informações disponíveis no site, e na melhor das hipóteses ele contará com atendimento via chat ou outro sistema de troca de mensagens instantâneas.

Além disso, na grande maioria dos casos, esses contratos são marcados pela impossibilidade de negociação de suas cláusulas, vindos preestabelecidos de forma unilateral pelo fornecedor, não havendo muita alternativa ao consumidor que opta pelo comércio eletrônico. Como afirma Lawand ${ }^{26}$, os contratos celebrados pela Internet podem ser considerados como contratos de adesão, ou seja, quando não é possibilitado ao consumidor a oportunidade de discutir e/ou modificar o conteúdo do contrato.

\footnotetext{
23 "Vulnerabilidade é uma situação permanente ou provisória, individual ou coletiva, que fragiliza, enfraquece o sujeito de direitos, desequilibrando a relação de consumo. Vulnerabilidade é uma característica, um estado do sujeito mais fraco, um sinal de necessidade e proteção". Em sua obra, Claudia Lima Marques também apresenta os três tipos de vulnerabilidade existentes, quais sejam: técnica, jurídica e fática, além de posteriormente acrescentar mais uma tipologia, chamada de vulnerabilidade informacional. BENJAMIN, A. H. V.; MARQUES, C. L.; BESSA, L. R, op. cit., p. 97-98.

${ }^{24}$ Bem ressalta Silva sobre isso: "Uma leitura superficial do tema poderia conduzir ao entendimento (equivocado, diga-se de passagem) de que os contratos eletrônicos não se distinguem dos demais contratos de consumo, bastando aplicar-lhe as mesmas regras já dispostas no Código de Defesa do Consumidor para solucionar eventuais conflitos. Ocorre que o uso das TIC permite novas aplicações e revela algumas especificidades, tanto na fase da sua formação, quanto na sua execução [...]". In: SILVA, Rosane Leal da. O direito privado desafiado pela dinâmica da contratação eletrônica: premissas para efetivar a proteção do consumidor brasileiro. In: SEMINÁRIO INTERNACIONAL DEMANDAS SOCIAIS E POLÍTICAS PÚBLICAS NA SOCIEDADE CONTEMPORÂNEA, 11., 2014, Santa Cruz do Sul. Anais... Santa Cruz do Sul: EDUNISC, 2014, v. 1, p. 1-18.

${ }^{25}$ SILVA, R. L. O direito privado desafiado pela dinâmica da contratação eletrônica: premissas para efetivar a proteção do consumidor brasileiro. In: In: SEMINÁRIO INTERNACIONAL DEMANDAS SOCIAIS E POLÍTICAS PÚBLICAS NA SOCIEDADE CONTEMPORÂNEA, 11., 2014, Santa Cruz do Sul. Anais... Santa Cruz do Sul: EDUNISC, 2014, v. 1, p. 1-18.

${ }^{26}$ LAWAND, J. J. op. cit., p. 57.
} 
Lawand $^{27}$ ressalta também a ideia do assincronismo, ou seja, de que as coisas não precisam necessariamente acontecer ao mesmo tempo quando se trata de um meio eletrônico. Isso afeta as regras que dizem respeito ao momento da formação do contrato e, consequentemente, sobre os direitos e deveres quanto à vinculação dos contratantes. Conforme Jorge Junior ${ }^{28}$, o momento da conclusão do contrato pode variar dependendo da modalidade de contratação eletrônica (intersistêmica, interpessoal, interativa).

Questão ainda mais angustiante é no tocante à onipresença da Web, ou seja, "significa que estando em um lugar, a sua presença se faz constante em todos os outros (efeito multiplicador de fazer negócios pela internet). Quem faz oferta de algum produto na Rede está fazendo para o mundo inteiro"29. Surge o problema apontado por Jorge Junior ${ }^{30}$ com relação ao lugar de formação do contrato e suas implicações na determinação da competência jurisdicional.

Tudo isso demonstra que as especificidades surgidas em função das novas tecnologias necessitam de um olhar cuidadoso da comunidade social e jurídica, visto que existem novas relações e situações a serem protegidas. Os próprios cidadãos consumidores perceberam isso antes mesmo do legislador e têm criado, de forma autônoma, mecanismos, através da Internet, para se proteger e se beneficiar ainda mais da contratação eletrônica. Esse é o ponto abordado a seguir.

\section{NOVAS FORMAS DE PROTEÇÃO DE DIREITOS: O CIBERATIVISMO DO CON- SUMIDOR 2.0 E AS FERRAMENTAS DE AVALIAÇÃO DAS RELAÇÕES DE CON- SUMO}

É natural que o Direito não logre acompanhar as transformações sociais, o que se dá pela assincronia existente entre as rápidas mudanças no mundo dos fatos e o tempo necessário para que haja um devido processo legislativo. As lacunas decorrentes desse fenômeno Bobbio ${ }^{31}$ denomina de "objetivas", e, segundo o autor, "são aquelas que dependem do desenvolvimento das relações sociais, das novas

\footnotetext{
${ }^{27}$ LAWAND, J. J. op. cit, p. 24.

${ }^{28}$ JORGE JUNIOR, A. G. Aspectos da formação e interpretação dos contratos eletrônicos. Revista do Advogado, São Paulo, v. 32, n. 115, p. 7-18, abr., 2012.

${ }^{29}$ LAWAND, J. J. op. cit., p. 24.

${ }^{30}$ JORGE JUNIOR, A. G. op. cit.

${ }^{31}$ BOBBIO, N. Teoria do Ordenamento Jurídico. São Paulo: EDIPRO, 2011, p. 140.
} 
invenções, de todas aquelas causas que provocam um envelhecimento dos textos legislativos e que, portanto, são independentes da vontade do legislador".

Desse modo, à medida que o contrato eletrônico surgia e o consumo virtual se popularizava, expandia-se a lacuna normativa em relação à regulação dessas práticas negociais. Ainda que as legislações já aplicáveis aos contratos tradicionais incidissem também sobre essa nova forma de contratação, muitas eram as novas situações que nasciam sem que houvesse um regramento específico. Somente anos após a popularização do consumo virtual foi editada uma norma para sua regulamentação.

Nesse interregno entre a difusão do consumo virtual e o advento de normas que o regulamentassem, os consumidores não restaram inertes diante de sua situação de vulnerabilidade, ao contrário: uniram-se e, com a adoção de uma postura proativa, criaram uma rede de autoproteção digital. Desse modo, os consumidores passaram a utilizar o mesmo local em que eram lesados - a Internet -, para reclamar, alertar e proteger os demais consumidores dessas situações.

Assim, surge o Consumidor 2.0,

[...] o qual utiliza a internet para demonstrar suas irresignações quando a busca da solução diretamente com a empresa não resolveu o conflito. [...] Como as pesquisas e compras foram realizadas nesse âmbito, ele também explicita a sua irresignação nesse meio, no intuito de compartilhá-la com outros consumidores e, se possível, ver o seu problema resolvido. Com esta atitude, ele visa garantir os seus direitos e ao mesmo tempo exigir uma contraprestação de qualidade ${ }^{32}$.

Ao se valerem da "rede mundial de computadores para divulgar suas reivindicações e desenvolver espaços de interação e de mobilização" 33 , os consumidores estão praticando, em realidade, uma forma de ativismo digital.

Tal ciberativismo consumerista originou-se com manifestações autônomas e independentes de consumidores em $b \operatorname{logs}$, redes sociais, páginas de compartilhamento de vídeos, em que eram publicadas revisões de produtos, elogios e reclamações de atendimentos, bem como alertas aos demais consumidores.

\footnotetext{
${ }^{32}$ RAMINELLI, F. P.; FELTRIN, L. P.; OLIVEIRA, R. S. de; CHRISTO, T. V. de. Ciberativismo do consumidor 2.0: limites e oportunidades ao exercício do direito de expressão no ciberespaço. Ambito Jurídico, Rio Grande, XIV, n. 92, set 2011. Disponível em: < http://www.ambito- juridico.com.br/site/index.php?artigo_id=10238\&n_ link= revista_artigos_leitura $>$. Acesso em: 20 ago. 2015.

${ }^{33}$ MORAES, D. O ativismo digital. Disponível em: < http:www.bocc.ubi.pt/pag/moraes-denis-ativismo-digital. html>. Acesso em: 27 jun. 2012.
} 
Posteriormente, com a constatação do alto potencial que os consumidores detinham de alterar a realidade de seus atendimentos ao publicitarem suas experiências, foram criados sites de iniciativa privada que visavam reunir em um só lugar tais manifestações, de modo que os consumidores tivessem um portal onde procurar informações sobre uma empresa antes de contratá-la, bem como as empresas pudessem verificar, em um só lugar, a avaliação que estava sendo feita do seu atendimento. Como exemplo dessas iniciativas tem-se o portal Reclame Aqui, o site Booking, a ferramenta E-bit, dentre outros. Dado o resultado positivo dessas experiências, o setor público adotou a ideia e foram disponibilizadas páginas de iniciativa governamental para manifestações consumeristas, tais quais o Portal da Agência Nacional de Telecomunicações e o site Consumigor.gov.br. Nesse sentido,

[...] muitos têm sido os sites na Internet que vêm reunindo este tipo de experiência consumerista e realizado um dossiê acerca das empresas mais reclamadas e da solução ou não dos problemas apresentados por seus consumidores. Assim, quando o consumidor se interessa por alguma empresa para realizar negócios, basta consultar em que nível está sua aprovação pelos consumidores, se o produto ou serviço atende às expectativas e, no caso de problemas pós-contratação, se a empresa possui um bom suporte ao consumidor. [...] Trata-se de uma opção ao ciberconsumidor, que, ao invés de criar seu próprio espaço online ou expor seus problemas em sua rede social, pode fazer em um ambiente já preparado para este fim, o qual notifica a empresa e leva em conta cada caso específico para classificá-la entre "boa" ou "ruim" para o consumidor ${ }^{34}$.

Dentre tantas iniciativas visando reunir as experiências dos consumidores em uma página virtual, destacou-se para análise neste estudo a E-bit por atuar somente na seara do comércio eletrônico, estar presente no mercado desde o ano 2000 e já ter coletado mais de 10 milhões de avaliações ${ }^{35}$. A empresa atua como um certificador de qualidade aos consumidores e

[...] possui um programa de avaliação criado para que os consumidores possam compartilhar suas experiências de compras e expressar suas opiniões sobre os serviços das lojas virtuais brasileiras. Essas avaliações são transformadas em medalhas, que podem ser Diamante, Ouro, Prata ou Bronze. Isso significa mais credibilidade para as lojas virtuais e mais segurança para os consumidores, que podem tomar uma decisão de compra de forma mais tranquila ${ }^{36}$.

\footnotetext{
${ }^{34}$ RAMINELLI, F. P.; OLIVEIRA, R. S. O consumidor ciberativista e as atuais ferramentas online para proteção de seus direitos: uma análise da evolução do site Reclame Aqui nos casos relativos a telecomunicações. In: VASCONCELOS, Fernando Antônio de; KNOERR, Viviane Coêlho de Séllos.; MARTINS, Fernando Rodrigues. (Org.). Direito do Consumidor. Florianópolis: Conpedi, 2014, p. 113-114.

${ }^{35}$ E-BIT. Conheça a E-bit. Disponível em: < http://www.ebit.com.br/conheca-ebit > Acesso em: 12 fev. 2015.

${ }^{36}$ E-BIT. Dúvidas frequentes. Disponível em: < http://www.ebit.com.br/faq-duvidas-frequentes $>$ Acesso em: 12 fev. 2015.
} 
A E-bit solicita que os clientes avaliem após a compra quesitos como facilidade de comprar, preço, manuseio dos produtos, cumprimento do prazo de entrega, informações dos produtos, entre outros. Os consumidores dão notas de 1 a 5, baseados em sua experiência de compra. As empresas que obtiverem nota geral inferior a 3 receberão a medalha bronze; já para receber a medalha prata, requer-se nota geral igual ou superior a 3 . Empresas com nota superior a 4 poderão receber as medalhas ouro ou diamante; para esta última exige-se também que o fornecedor garanta sigilo no tratamento de informações de clientes, tenha menos de $15 \%$ de atraso na entrega, obtenha índice igual ou superior a $85 \%$ em probabilidade de consumidores voltarem a comprar na loja, dentre outros requisitos ${ }^{37}$.

Pesquisas recentes revelam que as avaliações realizadas pelos consumidores têm tido forte influência sobre os demais no momento da compra ${ }^{38}$. Segundo os dados encontrados ${ }^{39}$, o consumo é o principal uso da Internet no Brasil. Nesse sentido, $58 \%$ dos internautas brasileiros costumam buscar informações na Internet antes de comprar algum produto, entre os integrantes da classe A o índice sobe para $84,3 \%{ }^{40}$. Ademais, cerca de metade dos internautas ativos afirma que informações postadas na Web afetam diretamente a decisão por adquirir ou não produtos e serviços $^{41}$. Como resultado desse fenômeno,

[...] faz-se necessário que a empresa esteja presente na web e, mais importante que isso, que esteja sendo bem comentada pelos usuários. (...) Tendo consciência do poder que o consumidor detém atualmente, imprescindível que haja um gerenciamento da sua reputação online. Ou seja, para a empresa e, de forma reflexa para consumidor, é muito interessante que haja um monitoramento acerca de conversas sobre a marca, revelando o que os clientes estão sugerindo ou reclamando ${ }^{42}$.

Esse fenômeno é positivo tanto para o fornecedor, o qual pode conhecer

${ }^{37}$ E-BIT. Conheça as medalhas E-bit. Disponível em: < http://www.ebit.com.br/medalhas=-e-bit;jsessionid327F27B7550390E64432D2DC760F63B5 > Acesso em: 12 fev. 2015.

${ }^{38}$ BAGUETE. Boca-a-Boca influencia 64 milhões de brasileiros. Disponível em: <http://www.baguete.com.br/ public/artigos/515/moriael-paiva/06/01/2009/boca-a-boca-influencia-64-milhoes-de-brasileiros $>$ Acesso em: 17 fev. 2015.

${ }^{39}$ Os dados mencionados são oriundos das pesquisas F/Radar, realizadas pela F/Nazca em conjunto com o Datafolha. As pesquisas são realizadas em intervalos anuais ou menores e avaliam questões relacionadas à Internet no Brasil, sobretudo cidadania, democracia e consumo.

${ }^{40}$ FNAZCA. F/radar 14a edição: internet móvel, cidadania e consumo no Brasil. Disponível em: < http://www. fnazca.com.br/wp-content/uploads/2014/12/fradar-14_publica-site.pdf > Acesso em: 25 mar. 2016.

${ }^{41}$ FNAZCA. F/radar $4^{a}$ edição. Disponível em: < http://www.fnazca.com.br/wp-content/uploads/2010/12/fradar_4a_edicao_agosto2008.pdf> Acesso em: 25 mar. 2016.

${ }^{42}$ FELTRIN, L. P.; OLIVEIRA, R. S. Consumidor 2.0 e o ciberativismo na web: transformações nas relações de consumo na era da informação digital. In: CONGRESSO NACIONAL DO CONPEDI: A Ordem Jurídica Justa Um diálogo Euroamericano. Florianópolis: Fundação Boiteux, 2011, v. 20, p. 11924-11925. Disponível em: $<$ http://www.conpedi.org.br/anais/XXcongresso/Integra.pdf>. Acesso em: 05 fev. 2015. 
melhor perfil, desejos e necessidades de seus clientes, quanto para o consumidor, o qual receberá um produto ou terá um serviço prestado com mais qualidade, tendo em vista a busca das empresas por manter uma boa reputação na Web.

Todavia, os critérios utilizados para uma boa ou má avaliação pelos consumidores nem sempre convergem com as exigências legais que uma empresa deve cumprir para respeitar o consumidor. Para auferir se as empresas mais bem avaliadas pelos consumidores são também aquelas que mais respeitam a legislação protetiva do consumidor, faz-se mister analisar qual o arcabouço normativo de proteção do consumo virtual em vigor no Brasil.

\title{
4 CONTRATOS ELETRÔNICOS: A LEGISLAÇÃO EM VIGOR NO BRASIL E SUA EFETIVIDADE A PARTIR DA ANÁLISE DOS SITES SELECIONADOS
}

Diante das relevantes mudanças sociais ocorridas no final do século XX, tais quais a globalização, o aumento do poder aquisitivo da população, a abertura do mercado nacional às importações, observou-se um amplo aumento do consumo. Nesse contexto, a nova ordem constitucional veio imbuída do ideal de proteção desse novo sujeito que emergia: o consumidor. Assim, foi com status de direito fundamental e de cláusula pétrea que a Constituição Federal de 1988 previu no bojo de seu artigo $5^{\circ}$ que o Estado promoveria, na forma da lei, a defesa do consumidor. Também, ao regular a ordem econômica, o texto constitucional previu, dentre um dos nove princípios que a regeria, a defesa do consumidor.

\begin{abstract}
Esse novo problema jurídico, ou seja, a proteção ao consumidor foi primeira levada ao plano penal para, em seguida, verificando a pouca eficiência penal em proteger o consumidor surgiu a necessidade de uma legislação específica de defesa do consumidor. Assim, o Código de Defesa do Consumidor foi erigido à condição de norma legislativa para tutelar amplamente o consumidor em face da sua fragilidade nas relações do consumo ${ }^{43}$.
\end{abstract}

No entanto, as previsões constitucionais de proteção ao consumidor eram muito genéricas; para que ocorresse a efetiva salvaguarda de seus direitos, faziase mister uma legislação mais específica, que disciplinasse de forma minuciosa

\footnotetext{
${ }_{43}$ REIS, C.; SANTOS, A. D. Responsabilidade civil, as relações de consumo e as diversas formas de publicidade ilícita. Revista Jurídica Cesumar Mestrado, v. 13, n. 2, 2013, p. 622. Disponível em: < http://periodicos.unicesumar.edu.br/index.php/revjuridica/article/view/3239/2141>. Acesso em: 26 fev. 2015.
} 
as relações de consumo. Nesse diapasão, o artigo 48 do Ato das Disposições Constitucionais Transitórias previu que o Congresso Nacional elaboraria um Código de Defesa do Consumidor dentro de cento e vinte dias.

Passaram-se quase dois anos desde a Constituição Federal de 1988 para que fosse promulgado o Código de Defesa do Consumidor, o qual surgiu com o objetivo de proteger integralmente o consumidor, vez que

Por ter a vulnerabilidade do consumidor diversas causas, não pode $o$ Direito proteger a parte mais fraca da relação de consumo somente em relação a alguma ou mesmo a algumas das facetas do mercado. Não se busca uma tutela manca do consumidor. Almeja-se uma proteção integral, sistemática e dinâmica ${ }^{44}$.

Ainda que o Código de Defesa do Consumidor (CDC) visasse à proteção integral do consumidor, as constantes e velozes alterações sociais, aliadas à incapacidade do processo legislativo de acompanhá-las, acarretaram a superveniência de situações em que o consumidor restasse desprotegido. Foi o que ocorreu com as relações de consumo virtual. Apesar de o CDC ser igualmente aplicável ao comércio eletrônico, novas questões surgiam sem que houvesse disciplina legal. Nesse sentido, Leal ${ }^{45}$ afirma que "Conquanto os meios eletrônicos mereçam atenção especial do legislador, enquanto isto não ocorrer, a segurança das relações jurídicas deve ser mantida, não se podendo deixar a descoberto as transações efetuadas em ambiente virtual". Assim,

[...] a Internet não cria espaço livre, alheio ao Direito. Ao contrário, as normas legais vigentes aplicam-se aos contratos eletrônicos basicamente da mesma forma que a quaisquer outros negócios jurídicos. A celebração de contratos via Internet se sujeita, portanto, a todos os preceitos pertinentes do Código Civil Brasileiro (Código Civil). Tratando-se de contratos de consumo, são também aplicáveis as normas do Código de Defesa do Consumidor (Código de Defesa do Consumidor $)^{46}$.

Ainda que totalmente aplicável o Código de Defesa do Consumidor ao consumo virtual, a popularização do comércio eletrônico fez surgir cada vez mais situações sem regramento legal, o que aumentou a vulnerabilidade do consumidor

\footnotetext{
${ }^{44}$ GRINOVER, A. P. et al. Código Brasileiro de Defesa do Consumidor: comentado pelos autores do anteprojeto. Rio de Janeiro: Forense, 2011, p. 4.

${ }^{45}$ LEAL, S. R. C. S. Contratos eletrônicos: validade jurídica dos contratos via Internet. São Paulo: Atlas, 2009, p. 92.

${ }^{46}$ LAWAND, J. J. Teoria geral dos contratos eletrônicos. São Paulo: J. de Oliveira, 2003, p. 59-60.
} 
virtual. Urgia a criação de uma legislação específica. Assim, no ano de 2013 foi aprovado o Decreto $\mathrm{n}^{0} 7.962$, o qual "Regulamenta a Lei $\mathrm{n}^{\circ}$ 8.078, de 11 de setembro de 1990, para dispor sobre a contratação no comércio eletrônico" ${ }^{\text {‘7 }}$. O Decreto veio sob aplausos de juristas como Filomeno ${ }^{48}$, para quem não há mister que se altere o Código de Defesa do Consumidor para adequá-lo às novas situações oriundas do comércio eletrônico, vez que o $\mathrm{CDC}$ não requer nenhum reparo, necessitando apenas de "regulamentação periférica, mediante a edição de decretos regulamentadores de alguns de seus aspectos para melhor aplicação de seus cânones" ${ }^{\prime 9}$.

De acordo com Silva $a^{50}$, "O escopo de tal decreto é dispor sobre as informações que devem estar à disposição do consumidor sobre o próprio fornecedor, os serviços ou produtos que serão negociados; facilitação do atendimento do consumidor e garantia do direito ao arrependimento". Nesse sentido, o Decreto traz quais são as informações mínimas que um sítio de consumo deve trazer, bem como algumas exigências a serem cumpridas. Em não sendo respeitado o texto legal, o Decreto prevê expressamente a aplicação das sanções administrativas do art. 56 do Código de Defesa de Consumidor. Destarte, fica claro que o Decreto vem para dar execução a um dos princípios do Código de Defesa do Consumidor: o princípio da transparência. Nesse sentido,

Na formação dos contratos entre consumidores e fornecedores o novo princípio básico norteador é aquele instituído pelo art. $4^{\circ}$, caput, do CDC, o da Transparência. A ideia central é possibilitar uma aproximação e uma relação contratual mais sincera e menos danosa entre consumidor e fornecedor ${ }^{51}$.

Consoante Marques $^{52}$, a transparência envolve informações claras e corretas sobre o produto e sobre o contrato, bem como lealdade nas relações entre consumidor e fornecedor, sobretudo na fase pré-contratual.

\footnotetext{
${ }^{47}$ BRASIL. Decreto $\mathrm{n}^{0}$ 7.962, de 15 de março de 2013. Regulamenta a Lei $\mathrm{n}^{\circ}$ 8.078, de 11 de setembro de 1990 , para dispor sobre a contratação no comércio eletrônico. Diário Oficial [da] República Federativa do Brasil, Brasília, 15 mar. 2013. Disponível em: < http://www.planalto.gov.br/ccivil_03/_ato2011-2014/2013/decreto/ d7962.htm >. Acesso em: 22 fev. 2015.

${ }^{48}$ FILOMENO, J. G. B. A tutela administrativa do consumidor: necessidade ou não de regulamentação do código de defesa do consumidor. In: FILOMENO, J. G. B. (Org.). Tutela administrativa do consumidor: atuação dos PROCONs, legislação, doutrina e jurisprudência. São Paulo: Atlas, 2015, p. 47-84.

${ }^{49}$ Ibidem, p. 49.

${ }^{50}$ SILVA, R. L. O direito privado desafiado pela dinâmica da contratação eletrônica: premissas para efetivar a proteção do consumidor brasileiro. In: SEMINÁRIO INTERNACIONAL DEMANDAS SOCIAIS E POLÍTICAS PÚBLICAS NA SOCIEDADE CONTEMPORÂNEA, 11., 2014. Anais... Santa Cruz do Sul: EDUNISC, 2014, v. 1, p. 12.

${ }^{51}$ MARQUES, C. L. Contratos no Código de Defesa do Consumidor: o novo regime das relações contratuais. São Paulo: Revista dos Tribunais, 1998, v. 1, p. 286.

${ }^{52}$ MARQUES, C. L. op. cit., p. 286.
} 
O Decreto entrou em vigor em 14 de maio de 2013. Passados já dois anos de sua publicação, transcorreu lapso temporal suficiente para que as empresas pudessem se adaptar às novas exigências legais. Cabe agora analisar o quanto a legislação está sendo observada por algumas lojas virtuais e avaliar se as empresas mais bem avaliadas pelos consumidores coincidem com aquelas que mais respeitam as normas protetivas do consumidor.

$\mathrm{O}$ art. $2^{\circ}$ do Decreto elenca uma série de condutas a serem observadas pelos fornecedores virtuais com relação ao dever de informar, que deve perpassar toda a contratação eletrônica. A informação, direito básico do consumidor (art. $6^{\circ}$ do CDC), possui algumas peculiaridades para o modelo eletrônico de contratação, visando atender à desmaterialização e despersonalização dos contratos virtuais e assim garantir a maior proteção do consumidor, ainda mais vulnerável nesse ambiente.

Conforme Benjamin, Marques e Bessa ${ }^{53}$, o direito à informação, constante no $\mathrm{CDC}$, é compreendido em todas as fases do contrato e integra a própria oferta, perspectiva que amplia a proteção do consumidor:

[...] a informação deve ser clara e adequada (arts. 12, 14, 18, 20, 30, $31,33,34,46,48,52$ e 54), esta nova transparência rege o momento pré-contratual, rege a eventual conclusão do contrato, o próprio contrato e o momento pós-contratual. É mais do que um simples elemento formal, afeta a essência do negócio, pois a informação repassada ou requerida integra o conteúdo do contrato $[\ldots]$.

No inciso I do referido artigo, a preocupação é no sentido de identificar o fornecedor, exigindo que o site de comércio eletrônico apresente o nome empresarial do fornecedor e o número de sua inscrição, quando houver, no Cadastro Nacional de Pessoas Físicas ou no Cadastro Nacional de Pessoas Jurídicas. Tal previsão é de suma importância, principalmente para responder, de certo modo, à despersonalização dos contratos virtuais, garantindo que o consumidor saiba com quem está contratando, evitando ser enganado nas suas negociações, bem como assegurando contra quem se dirigir em caso de problemas no cumprimento do contrato $^{54}$.

Os sites ora analisados apresentaram uma ou ambas as informações exigidas por lei. Cabe ressaltar que os sites disponibilizaram tais informações no rodapé da

\footnotetext{
$\overline{53}$ BENJAMIN, A. H. V.; MARQUES, C. L.; BESSA, L. R. op. cit., p. 73.

${ }^{54}$ SILVA, R. L. da. op. cit.
} 
página inicial ${ }^{55}$ e com a fonte reduzida. Lembra-se que a lei exige destaque e fácil visualização para tais informações. Uma das lojas (Loja 2) não apresentou o nome empresarial na página principal e com relação à Loja 4 não foi encontrada informação sobre o Cadastro Nacional. Segue o quadro com resultados da observação dos sítios virtuais:

Quadro 1. Resultados da avaliação dos sítios virtuais

\begin{tabular}{|l|l|}
\hline Loja 1 & Apresenta nome empresarial e CNPJ na página inicial. \\
\hline Loja 2 & Apresenta CNPJ na página inicial e o nome empresarial na sessão "quem somos". \\
\hline Loja 3 & Apresenta nome empresarial e CNPJ na página inicial. \\
\hline Loja 4 & Apresenta nome empresarial na página inicial. \\
\hline
\end{tabular}

Outra exigência legal bastante pertinente e necessária à contratação eletrônica está presente no inciso II do artigo $2^{\circ}$ do Decreto Regulamentador, ao exigir do fornecedor que informe, no próprio sítio virtual, seu endereço físico e virtual, bem como demais informações para localização e contato. Esta previsão segue a linha do inciso anterior, pois somente com tais informações o consumidor não há de ser prejudicado ao buscar a tutela de seus direitos pela via judiciária. Além disso, o inciso traz importante referência no sentido de facilitar o contato entre consumidor e fornecedor, visto que, muitas vezes, os problemas poderiam ser solucionados extrajudicialmente através de comunicação efetiva entre as partes.

Com relação a tais informações, verificou-se que há bastante discrepância na forma de disposição dos dados por parte dos fornecedores online. O endereço físico estava disponibilizado por todas as empresas, com fácil identificação em todos os sites. Quanto ao endereço virtual, somente a Loja 1 dispunha tal dado na página principal, enquanto na Loja 4 estava na sessão "quem somos". Ressalta-se que a Loja 2 e a Loja 4 também disponibilizaram mecanismo interno para envio de mensagem virtual ao fornecedor. Todas as lojas apresentaram telefones para atendimento ao consumidor, com fácil identificação em suas homepages. É interessante notar que a Loja 1 apresentou mais de uma sessão para localização física das suas lojas e a Loja 2 apresentou, dentro da sessão "onde estamos", descrição completa de como chegar à sede da loja. Já a Loja 3 obteve o resultado menos favorável, com menor quantidade de informações e sem mecanismo para contato entre consumidor e fornecedor.

\footnotetext{
${ }_{55}$ Neste artigo, como página principal/inicial entenda-se como sendo a página de entrada dos sítios eletrônicos, ou seja, a homepage.
} 
Quadro 2. Síntese das informações de contato existentes nos sites analisados

\begin{tabular}{|l|l|}
\hline Loja 1 & $\begin{array}{l}\text { Apresenta endereço físico e virtual; telefone do SAC; e possui as sessões "localizador } \\
\text { de lojas" e "atendimento loja física". }\end{array}$ \\
\hline Loja 2 & $\begin{array}{l}\text { Apresenta o endereço físico; telefone do SAC; e possui a sessão "fale conosco" e a } \\
\text { sessão "onde estamos". }\end{array}$ \\
\hline Loja 3 & Apresenta o endereço físico e ícone de acesso ao SAC. \\
\hline Loja 4 & Apresenta endereço físico e virtual; telefone do SAC; e possui a sessão "contato". \\
\hline
\end{tabular}

No inciso III, a preocupação se desloca da pessoa do contratante para o produto ou serviço adquirido, sendo dever do fornecedor trazer as características essenciais, bem como riscos à saúde e segurança dos consumidores com relação ao objeto da relação contratual. Tal previsão atende ao fato do consumidor adquirir um produto/serviço à distância, sem o menor contato físico prévio, sendo de fundamental importância a mais minuciosa descrição informativa.

Quanto ao comportamento do fornecedor de prestar informação falsa ou enganosa ou omitir informação relevante sobre o produto através da Internet, Filomeno ${ }^{56}$ destaca que tal conduta pode inclusive configurar crime, que muito se assemelha ao delito de falsidade ideológica, porém com ele não se confunde, vez que há tipificação expressa do crime específico para as relações de consumo no Código de Defesa do Consumidor.

Ao observar os sítios virtuais, todas as Lojas apresentaram informações com relação aos produtos ofertados. Quanto às especificações técnicas, a Loja 1 apresentou maior número de dados e a Loja 3 não apresentou qualquer especificação técnica sobre seus produtos. Percebeu-se que as sessões "detalhes do produto", "sinopse" e "descrição" se equivalem, ambas apresentando uma descrição geral do produto a ser adquirido. Com relação aos riscos e segurança, nenhuma Loja apresentou qualquer informação, nem mesmo negativa.

Quadro 3. Síntese da presença ou não de especificações técnicas dos produtos

\begin{tabular}{|l|l|}
\hline Loja 1 & $\begin{array}{l}\text { Apresenta as sessões "detalhes do produto"; “características"; e "especificações } \\
\text { técnicas". }\end{array}$ \\
\hline Loja 2 & Apresenta as sessões "sinopse"; e "informações". \\
\hline Loja 3 & Apresenta ementa com descrição do produto. \\
\hline Loja 4 & Apresenta as sessões "descrição"; "sobre o autor"; e "dados técnicos". \\
\hline
\end{tabular}

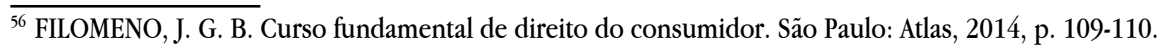


$\mathrm{O}$ inciso IV também assegura direito essencial ao consumidor, exigindo ao fornecedor que informe, de antemão, sobre quaisquer custos adicionais ou acessórios, como frete ou seguros, conforme exemplifica a própria norma. Tal previsão é essencial nas contratações eletrônicas, visto não ser admissível que o consumidor, posteriormente, venha a ser surpreendido com a cobrança de taxa extra para a entrega, por exemplo. Quanto ao seguro, da mesma forma, ao consumidor deve ser assegurado o direito de escolha sobre tal contratação, configurando como abusivo o fornecimento de um serviço não solicitado, gerando custo extra ao consumidor.

Com relação às páginas analisadas, percebeu-se que, em regra, há informação clara a respeito das taxas com transporte do produto. Nas Lojas 1 e 2 , o cálculo podia ser feito rapidamente, sendo disponibilizado na própria página da oferta. Na Loja 3 não havia nenhuma informação sobre a entrega na página da oferta do produto, no entanto, não se pode afirmar que não há discriminação de valores com relação a isso nas próximas etapas de compra. Já na Loja 4, na página da oferta, logo após o preço, constava a seguinte informação: "taxa de entrega não está incluída".

Quadro 4. Síntese da presença ou não de informações sobre taxas com transporte do produto

\begin{tabular}{|l|l|}
\hline Loja 1 & Possui mecanismo para cálculo do frete. \\
\hline Loja 2 & Possui mecanismo para cálculo do frete. \\
\hline Loja 3 & Não foi possível identificar. \\
\hline Loja 4 & Apresenta informação sobre a taxa de entrega. \\
\hline
\end{tabular}

$\mathrm{O}$ inciso $\mathrm{V}$, por sua vez, trata da oferta, instituto de grande importância no direito do consumidor, que prevê a vinculação do contratante aos termos da oferta. No que diz respeito aos contratos eletrônicos, o Decreto 7962 exige que o fornecedor informe as condições integrais da oferta, incluindo modalidade de pagamento, disponibilidade, forma e prazo para execução do contrato. A preocupação do legislador, com a norma, foi tentar responder ao processo de desmaterialização dos contratos eletrônicos, causador de inseguranças na realização desse tipo de contratação.

$\mathrm{Na}$ análise, verificou-se que os sites, em geral, trazem informações referentes ao pagamento logo na página da oferta, inclusive especificando todas as possibilidades 
de parcelamento, com indicação discriminada de valores, como é o caso da Loja 1 e Loja 4. Quanto à Loja 2, na página da oferta somente havia informação sobre o valor a pagar e uma especificidade quanto ao pagamento por boleto, sem nenhuma explicação sobre outras modalidades. A Loja 3 apresentou informação discriminada sobre os valores da assinatura de seus produtos. Com relação à execução do contrato, as Lojas 1 e 2 possibilitavam ao consumidor calcular o prazo de entrega do produto. As outras lojas, ao menos na página da oferta, não tinham qualquer informação a respeito. Ressalta-se que a Loja 3 pode ter falha nesse sentido em função de ofertar assinaturas de revistas, as quais são enviadas mensalmente aos consumidores. As Lojas 1, 2 e 3 apresentaram páginas específicas para atendimento de dúvidas, com informações acerca de pagamento, entrega e disponibilidade.

Quadro 5. Síntese da presença ou não de informações claras e precisas sobre modalidade de pagamento

\begin{tabular}{|l|l|}
\hline Loja 1 & $\begin{array}{l}\text { Apresenta as modalidades de pagamento, bem como sobre incidência ou não de } \\
\text { juros. Possui mecanismo para cálculo do prazo de entrega. }\end{array}$ \\
\hline Loja 2 & $\begin{array}{l}\text { Apresenta informação sobre modalidade de pagamento. Possui mecanismo para } \\
\text { cálculo do prazo de entrega e informação referente à disponibilidade do produto. }\end{array}$ \\
\hline Loja 3 & Apresenta informações discriminadas sobre pagamento. \\
\hline Loja 4 & $\begin{array}{l}\text { Apresenta as modalidades de pagamento, bem como sobre incidência ou não de } \\
\text { juros. }\end{array}$ \\
\hline
\end{tabular}

Com relação ao inciso VI, este é um complemento da previsão acerca das características essenciais do produto e dos termos da oferta, que devem ser devidamente informadas pelo fornecedor. Nesse caso, trata-se sobre as restrições à fruição da oferta, que devem ser especificadas ao consumidor. Quanto às páginas virtuais analisadas, não se verificou nenhuma informação com relação ao exposto na legislação.

$\mathrm{O}$ artigo $5^{\circ}$ do Decreto também merece destaque, pois amplia a previsão do Código de Defesa do Consumidor sobre o direito ao arrependimento. Com relação ao contrato eletrônico, segundo esse artigo, deve o fornecedor apresentar informações claras e ostensivas para o exercício do arrependimento. Os parágrafos especificam como deverá ser o procedimento adotado pelas partes, garantindo a efetivação do direito sem qualquer ônus ao consumidor. Quanto ao caput, que 
ressalta o direito à informação, este se revela extremamente pertinente à situação, pois dificilmente os consumidores, em sua maioria leigos, saberão do direito ao arrependimento que lhes é garantido nas contratações à distância.

Ao verificar as Lojas virtuais aqui analisadas quanto ao dever de informação, somente na Loja 3 não foi encontrada qualquer informação sobre o direito de arrependimento. Todas as outras lojas informavam sobre o arrependimento em páginas específicas para este fim. Em nenhuma loja a informação constava na própria página da oferta. Assim, para tomar conhecimento de tal direito, espera-se uma conduta ativa do consumidor, pesquisando no sítio virtual. Ocorre que, na maioria das vezes, o consumidor tem desconhecimento desse direito, o que dificilmente o fará buscar algo que não sabe que existe.

Quadro 6. Síntese da presença ou não de informações sobre arrependimento

\begin{tabular}{|l|l|}
\hline Loja 1 & Informação sobre arrependimento na sessão "política de troca e devolução". \\
\hline Loja 2 & Informação sobre arrependimento na sessão "política de vendas". \\
\hline Loja 3 & Não se verificou qualquer informação a respeito. \\
\hline Loja 4 & Informação sobre arrependimento na sessão "dúvidas". \\
\hline
\end{tabular}

As situações de recorrente reclamação por parte dos consumidores se dão pela precariedade no cumprimento e respeito a esse artigo, como, por exemplo, nos casos de: falta de informaçóes; falta ou atraso na entrega do produto; pouca clareza dos termos do contrato; vício ou defeito do produto; desconformidade do produto recebido com as características apresentadas no sítio virtual; frustração da expectativa ao receber o produto; indisponibilidade do produto após realizada a compra; dentre outros. Assim, fica evidente que a diminuição dos problemas com relação aos contratos eletrônicos perpassa a observância aos deveres elencados nesse artigo, ou seja, garantia de informações de forma ampla e efetivo cumprimento das condições ofertadas.

No primeiro inciso do artigo $4^{\circ}$ do Decreto, é prevista a exigência de que seja apresentado ao consumidor o sumário do contrato antes da contratação, o qual deve enfatizar cláusulas que limitem direitos. Essa previsão é de absoluta importância, vez que, somente com o conhecimento prévio dos temos da contratação, pode-se assegurar o pleno exercício do livre direito de escolha do consumidor. Além disso, o destaque às cláusulas limitativas de direitos é essencial no contexto de contratação adesiva ao qual o consumidor está normalmente inserido. Dentre os quatro sítios 
analisados, apenas um (Loja 3) apresentou sumário do contrato antes da contratação, todavia não grifou as cláusulas limitativas de direitos.

Quadro 7. Síntese da presença ou não do sumário do contrato antes da contratação

\begin{tabular}{|l|l|}
\hline Loja 1 & Não foi encontrado sumário do contrato antes da contratação. \\
\hline Loja 2 & Não foi encontrado sumário do contrato antes da contratação. \\
\hline Loja 3 & $\begin{array}{l}\text { Após clicar em "quero assinar", o consumidor é direcionado às páginas "identificação" } \\
\text { e, posteriormente, "fase de entrega". Esta última etapa exige que, para prosseguir } \\
\text { com a contratação, clique-se em "li e aceito os termos de uso", em que há um link que } \\
\text { apresenta o contrato de compra e venda de assinaturas pela Internet. No contrato, } \\
\text { estão grifadas as referências aos contratantes, às pessoas jurídicas envolvidas, ao } \\
\text { serviço de atendimento ao consumidor e a prazos do contrato. Além disso, em todas } \\
\text { as páginas de visualização de produtos do site se mantém na parte inferior o link } \\
\text { "contrato de assinatura". }\end{array}$ \\
\hline Loja 4 & Não foi encontrado sumário do contrato antes da contratação. \\
\hline
\end{tabular}

Situação recorrente no comércio eletrônico é que, ao encerrar sua compra, o consumidor perceba que não a realizou nos exatos termos em que desejava, devido a um erro no processo de contratação. Para evitar que equívocos durante a contratação resultem em negociações indesejadas, há de se fornecer ferramentas eficazes ao consumidor para identificação e correção de possíveis erros que tenham ocorrido nas etapas anteriores à finalização da contratação. Exatamente essa é a postura que o art. $4^{\mathrm{o}}$, inciso II do Decreto exige das páginas virtuais. Na pesquisa realizada, identificou-se que três das quatro lojas analisadas oportunizavam, em momentos distintos, a correção de possíveis erros.

Quadro 8. Síntese da presença ou não da possibilidade de correção de erros antes de finalizar a compra

(continua)

Loja 1

Após clicar em "concluir compra", é apresentado ao consumidor o "resumo carrinho", página em que são apresentados, sinteticamente, os produtos selecionados e o total a pagar. Logo acima, há o botão "alterar", através do qual é possível corrigir as seleções feitas na etapa anterior da contratação. Após, passa-se para a fase de identificação, em que essa opção é suprimida. Nas fases "endereço" e "pagamento" novamente essa opção de alteração é apresentada. 
(conclusão)

\begin{tabular}{|l|l|}
\hline Loja 2 & $\begin{array}{l}\text { Ao clicar na opção "comprar", o cliente é encaminhado à página do "carrinho de } \\
\text { compra", na qual ainda é possível realizar alterações no pedido corrigindo erros } \\
\text { cometidos. Após, o cliente é encaminhado às páginas "identificação", "dados da } \\
\text { entrega" e "confirmação e pagamento". Nestas últimas três páginas não é mais } \\
\text { possível alterar opçôes realizadas anteriormente. }\end{array}$ \\
\hline Loja 3 & $\begin{array}{l}\text { Ao clicar em "quero assinar", o cliente é direcionado sucessivamente às páginas } \\
\text { "identificação", "entrega", "pagamento" e "finalização". Em todas elas não é } \\
\text { disponibilizada a opção de alterar escolhas feitas anteriormente. }\end{array}$ \\
\hline Loja 4 & $\begin{array}{l}\text { Ao clicar na opção "comprar", o cliente é encaminhado à página "meu carrinho", } \\
\text { na qual ainda é possível realizar alterações no pedido corrigindo erros } \\
\text { realizados. Após, o cliente é encaminhado às páginas "identificação", "entrega" } \\
\text { e "pagamento". Nestas últimas três páginas não é mais possível alterar opções } \\
\text { realizadas anteriormente. }\end{array}$ \\
\hline
\end{tabular}

Nesse diapasão, os incisos III e IV do artigo quarto do Decreto dispõem que o fornecedor deve confirmar imediatamente ao consumidor o recebimento da aceitação da oferta, bem como disponibilizar ao consumidor, imediatamente após a contratação, cópia do contrato em meio que permita sua conservação e reprodução. As previsões são de extrema relevância para que o consumidor possa ter certeza de que sua compra foi efetuada e para que possa reivindicar os direitos que eventualmente lhe foram assegurados no contrato. Contudo, a análise de ambos dispositivos restou prejudicada, vez que exigiria que fosse efetuada uma contratação nas páginas virtuais analisadas.

O direito à informação é um direito básico do consumidor (art. $6^{\circ}$, III do CDC) que norteia todo o sistema protetivo do $\mathrm{CDC}$, haja vista que, somente com acesso à informação adequada, pode-se assegurar que a contratação realizada seja realmente fruto de uma vontade livre. Nesse sentido, com vistas a minimizar a escassez de informação que o consumidor vivencia face à desmaterialização e despersonalização do contrato, o inciso $\mathrm{V}$ do artigo $4^{\circ}$ do Decreto dispõe que a empresa deverá manter serviço adequado e eficaz de atendimento em meio eletrônico, que possibilite ao consumidor a resolução de demandas referentes a informação, dúvida, reclamação, suspensão ou cancelamento do contrato.

Todas as empresas investigadas possuem algum serviço de atendimento, entretanto questiona-se se esses seriam adequados e eficazes, conforme exige a norma, haja vista que muitos não são gratuitos ou possuem longas filas de espera. 
Quadro 9. Síntese da adequação do serviço de atendimento

\begin{tabular}{|l|l|}
\hline Loja 1 & $\begin{array}{l}\text { A empresa oferece as opções de contato através de chat (de segunda a sábado, das 8h } \\
\text { às 20h), via e-mail (preenchendo-se formulário eletrônico) e por telefone (de segunda } \\
\text { a sábado). Destaque-se que a ligação telefônica não é gratuita, o chat possui uma longa } \\
\text { fila de espera e as mensagens de e-mail precisam ser enquadradas em assuntos pré- } \\
\text { definidos. }\end{array}$ \\
\hline Loja 2 & $\begin{array}{l}\text { A empresa oferece as opções de contato através de e-mail (preenchendo-se formulário } \\
\text { eletrônico) e por telefone (de segunda a sexta). Destaque-se que a ligação telefônica } \\
\text { não é gratuita. }\end{array}$ \\
\hline Loja 3 & $\begin{array}{l}\text { A empresa oferece as opções de contato através de chat e via e-mail (preenchendo-se } \\
\text { formulário eletrônico). }\end{array}$ \\
\hline Loja 4 & $\begin{array}{l}\text { A empresa oferece as opções de contato através de e-mail (preenchendo-se formulário } \\
\text { eletrônico) e por telefone. Destaque-se que a ligação telefônica não é gratuita. }\end{array}$ \\
\hline
\end{tabular}

Após se utilizar do serviço virtual de atendimento da empresa, frequentemente o consumidor demora a receber um retorno a ponto de se indagar se, talvez, sua demanda não teria sido recebida. Por essa razão, o inciso VI do artigo quarto do Decreto preceitua que após o envio da dúvida, seja confirmado imediatamente, pelo mesmo meio empregado pelo consumidor, o recebimento da demanda. Nesse aspecto, todas as empresas analisadas estão cumprindo a exigência legal.

Quadro 10. Síntese do cumprimento ou não do envio de confirmação de recebimento de demanda do consumidor

\begin{tabular}{|l|l|}
\hline Loja 1 & $\begin{array}{l}\text { Após envio de uma dúvida, foi informado imediatamente o seu recebimento, } \\
\text { pelo mesmo meio que havia sido empregado para seu envio. }\end{array}$ \\
\hline Loja 2 & $\begin{array}{l}\text { Após envio de uma dúvida, foi informado imediatamente o seu recebimento, } \\
\text { pelo mesmo meio que havia sido empregado para seu envio. }\end{array}$ \\
\hline Loja 3 & $\begin{array}{l}\text { Após envio de uma dúvida, foi informado imediatamente o seu recebimento, } \\
\text { pelo mesmo meio que havia sido empregado para seu envio. }\end{array}$ \\
\hline Loja 4 & $\begin{array}{l}\text { Após envio de uma dúvida, foi informado imediatamente o seu recebimento, } \\
\text { pelo mesmo meio que havia sido empregado para seu envio. }\end{array}$ \\
\hline
\end{tabular}

Ainda abordando a questão do envio de dúvidas, o parágrafo único do artigo quarto do decreto determina que a resposta do fornecedor às demandas submetidas pelo consumidor deverá ser encaminhada em até cinco dias ao consumidor. Fezse necessário estabelecer um prazo para resposta devido ao recorrente descaso 
no atendimento ao consumidor. Infelizmente, a constatação foi que o tratamento dispensado ao consumidor mantém-se negligente, mesmo com a determinação legal em vigor, somente duas das empresas analisadas cumpriram o prazo legal para responder ao consumidor.

Quadro 11. Síntese do cumprimento ou não do prazo de 5 dias para resposta ao consumidor

\begin{tabular}{|l|l|}
\hline Loja 1 & $\begin{array}{l}\text { Foi enviada mensagem por e-mail tão logo ocorreu o envio da dúvida, a mensagem } \\
\text { notifica o recebimento da dúvida e informa que ela será respondida em até 4 } \\
\text { dias úteis. Passado mais de um mês desde o contato com a loja, a dúvida não foi } \\
\text { respondida. }\end{array}$ \\
\hline Loja 2 & $\begin{array}{l}\text { Um dia após o contato com a loja, foi enviada resposta por e-mail respondendo a } \\
\text { dúvida encaminhada. }\end{array}$ \\
\hline Loja 3 & $\begin{array}{l}\text { Quatorze dias após o contato com a loja, foi enviada resposta por e-mail } \\
\text { respondendo a dúvida encaminhada. }\end{array}$ \\
\hline Loja 4 & $\begin{array}{l}\text { Um dia após o contato com a loja, foi enviada resposta por e-mail respondendo a } \\
\text { dúvida encaminhada. }\end{array}$ \\
\hline
\end{tabular}

Por fim, o inciso VII do art. $4^{\mathrm{o}}$ do Decreto exige que os fornecedores utilizem mecanismos de segurança eficazes para pagamento e para tratamento de dados do consumidor. Essa necessidade se dá ante a frequência com que computadores são invadidos, dados são capturados e contratações indesejadas são feitas às custas do consumidor. Três das quatro lojas analisadas informaram utilizar algum mecanismo de segurança em suas operações.

Quadro 12. Síntese quanto aos mecanismos de segurança para pagamento e tratamento de dados do consumidor

\begin{tabular}{|l|l|}
\hline Loja 1 & $\begin{array}{l}\text { A loja oferece a opção de pagamento pelo sistema PayPal, bem como por cartão de } \\
\text { crédito, boleto bancário, débito online, multicheque/multicash, cartão presente, } \\
\text { minha casa melhor, masterpass. }\end{array}$ \\
\hline Loja 2 & $\begin{array}{l}\text { A loja oferece pagamento mediante boleto bancário ou cartão de crédito. A página } \\
\text { indica utilizar os sistemas SSL (Secure Socket Layer) e Trust Sign. }\end{array}$ \\
\hline Loja 3 & $\begin{array}{l}\text { Estão disponíveis as opções de pagamento por cartão de crédito e débito em conta. A } \\
\text { empresa não informa a utilização de algum sistema de segurança. }\end{array}$ \\
\hline Loja 4 & $\begin{array}{l}\text { As opções de pagamento ofertadas são cartão de crédito, boleto bancário e depósito. } \\
\text { A loja informa utilizar os sistemas FControl e Thawte. }\end{array}$ \\
\hline
\end{tabular}

Percebe-se que, de uma formageral, diversas exigências constantes no Decreto 7.962/2013 foram atendidas pelos fornecedores, não havendo um descumprimento 
absoluto da norma. Isso demonstra certa preocupação dos fornecedores a adequarse às novas exigências regulamentares, embora tal preocupação não seja tamanha a ponto de o cumprimento ser total. Resta verificar agora se os sites dos fornecedores melhor avaliados pelos consumidores na ferramenta E-bit correspondem aos sites que mais atendem aos ditames do Decreto 7.962 de 2013.

\section{CONSIDERAÇÕES FINAIS}

As mudanças operadas com o advento das novas tecnologias são intensas, tendo inclusive alterado a maneira como as pessoas realizam contratos entre $\mathrm{si}$. $\mathrm{Na}$ dimensão consumerista, as relações privadas sofrem com a despersonalização e desmaterialização dos contratos realizados por meio da Internet. Em função disso, ganhou espaço na Internet páginas virtuais onde os próprios consumidores relatam as experiências que vivenciam com a contratação eletrônica e avaliam as empresas, como é o caso do E-bit. No entanto, a necessidade de avanço legislativo revelou-se fundamental para a proteção para esse consumidor, tendo sido editado, em 2013, o Decreto 7.962 para regulamentar a contratação eletrônica.

Nessa perspectiva, questiona-se se os sites dos fornecedores melhor avaliados pelos consumidores na ferramenta $E$-bit correspondem aos sites que mais atendem às exigências da legislação. Após a análise das quatro páginas virtuais selecionadas por categoria em ordem classificatória de avalição, pode-se verificar que, mesmo estando estratificadas por ordem de melhor avaliação, os critérios da legislação não têm correspondência direta com a classificação dos sites.

Com relação aos artigos $2^{\circ}$ e $5^{\circ}$ do Decreto, no que tange ao direito à informação, observou-se que tanto as lojas mais bem avaliadas, como as pior avaliadas, estão atentas ao dever de informação que devem prestar em suas páginas virtuais. Somente uma das páginas, a da Loja 3, apresentou alguns dados inconclusivos, visto que não foi possível identificar se havia ou não observância do dever de informar. Quanto às outras lojas, cada uma de uma maneira específica, apresentou todos os dados necessários conforme os arts. $2^{\circ}$ e o art. $5^{\circ}$.

Com relação ao art. $4^{\circ}$, que trata de requisitos mais específicos, também apresenta resultados em que não há uma direta correspondência entre a ordem classificatória e o cumprimento da legislação. Conforme se verificou, os incisos que 
tratam do serviço de atendimento em meio virtual e confirmação de recebimento de demanda (V, VI) foram atendidos por todas as lojas verificadas. Já quanto ao sumário do contrato somente a Loja 3 apresentou cumprimento da exigência. Verificou-se que as Lojas 1, 2 e 4 atenderam à lei quanto à possibilidade de correção de erros, bem como quanto à exigência de mecanismos de segurança para pagamento, enquanto as Lojas 2 e 4 também responderam as dúvidas dentro do prazo exigido pela legislação.

Pode-se sistematizar os dados da seguinte forma: dos 12 quesitos avaliados em todas as lojas, a Loja 1 apresentou adequação em 10 desses quesitos; a Loja 2 em 11 quesitos; a Loja 3 em 7 quesitos; e a Loja 4 em 11 quesitos. Assim, conclui-se que os requisitos a serem cumpridos pela legislação não são os fatores determinantes para caracterização de uma empresa como boa pelo consumidor ativista. No entanto, isso se deve ao fato de que, geralmente, as avaliações dos consumidores baseiam-se nas próprias experiências por eles vivenciadas e não a partir de quesitos abstratamente previstos. As principais reclamações comumente dizem respeito ao não recebimento do pedido, falta de atendimento, vícios ou defeitos dos produtos, atraso na entrega, indisponibilidade do produto, dentre outros. Ocorre que a devida solução desses problemas, bem como sua prevenção, passa pelas exigências legais, que pautam, principalmente, o dever de informação e atendimento adequado por parte do fornecedor virtual.

Dessa forma, torna-se imperioso o cumprimento da legislação que regula as condições para contratação eletrônica adequada, de modo a proteger o consumidor nessa relação cada vez mais despersonalizada e desmaterializada através da Internet.

\section{REFERÊNCIAS}

BAGUETE. Boca-a-Boca influencia 64 milhões de brasileiros. Disponível em: $<$ http://www.baguete.com.br/public/artigos/515/moriael-paiva/06/01/2009/boca-aboca-influencia-64-milhoes-de-brasileiros $>$. Acesso em: 17 fev. 2015.

BARBAGALO, Erica Brandini. Contratos eletrônicos. São Paulo: Saraiva, 2001.

BENJAMIN, Antonio Herman V.; MARQUES, Claudia Lima; BESSA, Leonardo Roscoe. Manual de Direito do Consumidor. São Paulo: Revista dos Tribunais, 2013. 
BOBBIO, Norberto. Teoria do ordenamento jurídico. São Paulo: EDIPRO, 2011.

BRASIL. Constituição (1988). Constituição da República Federativa do Brasil: texto constitucional promulgado em 5 de outubro de 1988, com as alterações adotadas pelas Emendas Constitucionais $\mathrm{n}^{0}$ 1/1992 a 70/2012, pelo Decreto Legislativo ${ }^{0}$ 186/2008 e pelas Emendas Constitucionais de Revisão $n^{0} 1$ a 6/1994. 36. ed. Brasília: Câmara dos Deputados, Edições Câmara, 2012.

BRASIL. Decreto $\mathrm{n}^{\circ}$ 7.962, de 15 de março de 2013. Regulamenta a Lei ${ }^{\circ}$ 8.078, de 11 de setembro de 1990, para dispor sobre a contratação no comércio eletrônico. Diário Oficial [da] República Federativa do Brasil, Brasília, 15 mar. 2013. Disponível em: < http://www.planalto.gov.br/ccivil_03/_ato2011-2014/2013/decreto/d7962.htm > . Acesso em: 22 fev. 2015.

E-BIT. Conheça a E-bit. Disponível em: < http://www.ebit.com.br/conheca-ebit>. Acesso em: 12 fev. 2015.

E-BIT. Conheça as medalhas E-bit. Disponível em: <http://www.ebit.com.br/ medalhas-e-bit;jsessionid $=327 F 27 B 7550390 E 64432 \mathrm{D} 2 \mathrm{DC} 760 \mathrm{~F} 63 \mathrm{~B} 5>$. Acesso em: 12 fev. 2015.

E-BIT. Dúvidas frequentes. Disponível em: < http://www.ebit.com.br/faq-duvidasfrequentes $>$. Acesso em: 12 fev. 2015.

FELTRIN, Lohana Pinheiro; OLIVEIRA, Rafael Santos de. Consumidor 2.0 e o ciberativismo na web: transformações nas relações de consumo na era da informação digital. In: CONGRESSO NACIONAL DO CONPEDI: A Ordem Jurídica Justa - Um diálogo Euroamericano, 20., 2011. Anais... Florianópolis: Fundação Boiteux, 2011, v. 20, p. 11917-11934. Disponível em: < http://www.conpedi.org.br/anais/ XXcongresso/Integra.pdf > . Acesso em: 05 fev. 2015.

FILOMENO, José Geraldo Brito. A tutela administrativa do consumidor: necessidade ou não de regulamentação do código de defesa do consumidor. In: FILOMENO, José Geraldo Brito. (Org.). Tutela administrativa do consumidor: atuação dos PROCONs, legislação, doutrina e jurisprudência. São Paulo: Atlas, 2015.

FILOMENO, José Geraldo Brito. Curso fundamental de direito do consumidor. São Paulo: Atlas, 2014. 
FNAZCA. F/radar 14a edição: internet móvel, cidadania e consumo no Brasil. Disponível em: <http://www.fnazca.com.br/wp-content/uploads/2014/12/ fradar-14_publica-site.pdf > . Acesso em: 25 mar. 2016.

FNAZCA. F/radar $4^{\mathbf{a}}$ edição. Disponível em: <http://www.fnazca.com.br/wpcontent/uploads/2010/12/fradar_4a_edicao_agosto2008.pdf>. Acesso em: 25 mar. 2016.

GRINOVER, Ada Pellegrini et al. Código Brasileiro de Defesa do Consumidor: comentado pelos autores do anteprojeto. Rio de Janeiro: Forense, 2011.

JORGE JUNIOR, Alberto Gosson. Aspectos da formação e interpretação dos contratos eletrônicos. Revista do Advogado, São Paulo, v. 32, n. 115, p. 7-18, abr., 2012.

LAWAND, Jorge José. Teoria geral dos contratos eletrônicos. São Paulo: J. de Oliveira, 2003.

LIMA, Jairo Néia; CAMBI, Eduardo Augusto Salomão. Os efeitos irradiantes da Constituição sobre o Direito Privado: seu processo de constitucionalização. Revista Jurídica Cesumar - Mestrado, v. 11, n. 2, jul./dez. 2011, p. 451-470.

LEAL, Sheila do Rocio Cercal Santos. Contratos eletrônicos: validade jurídica dos contratos via Internet. São Paulo: Atlas, 2009.

LÔBO, Paulo Luiz Netto. Constitucionalização do Direito Civil. Revista de Informação Legislativa, Brasília, v. 36, n. 141, jan./mar. 1999. Disponível em: < http://www2. senado.leg.br/bdsf/bitstream/handle/id/453/r141-08.pdf?sequence $=4>$. Acesso em: 25 maio. 2015.

MARQUES, Cláudia Lima. Contratos no Código de Defesa do Consumidor: o novo regime das relações contratuais. São Paulo: Revista dos Tribunais, 1998, v. 1.

MARQUES, Cláudia Lima. Diálogo entre o Código de Defesa do Consumidor e o novo Código Civil: do "Diálogo das Fontes" no combate às cláusulas abusivas. Revista de Direito do Consumidor, v. 45, ano 12, jan./mar. 2003.

MARTINS-COSTA, Judith; BRANCO, Gerson Luiz Carlos. Diretrizes Teóricas do Novo Código Civil Brasileiro. São Paulo: Saraiva, 2002. 
MORAES, Dênis de. $\mathbf{O}$ ativismo digital. Disponível em: < http:www.bocc.ubi.pt/ pag/moraes-denis-ativismo-digital.html> . Acesso em: 27 jun. 2012.

RAMINELLI, Francieli Puntel; FELTRIN, Lohana Pinheiro; OLIVEIRA, Rafael Santos de; CHRISTO, Tatiana Vielmo de. Ciberativismo do consumidor 2.0: limites e oportunidades ao exercício do direito de expressão no ciberespaço. Ambito Jurídico, Rio Grande, v. XIV, n. 92, set. 2011. Disponível em: < http://www. ambitojuridico.com.br/site/index.php?artigo_id $=10238 \&$ n_link $=$ revista_artigos_ leitura >. Acesso em: 20 ago. 2015.

RAMINELLI, Francieli Puntel; OLIVEIRA, Rafael Santos de. O consumidor ciberativista e as atuais ferramentas online para proteção de seus direitos: uma análise da evolução do site Reclame Aqui nos casos relativos a telecomunicações. In: VASCONCELOS, Fernando Antônio de; KNOERR, Viviane Coêlho de Séllos.; MARTINS, Fernando Rodrigues. (Org.). Direito do Consumidor. Florianópolis: Conpedi, 2014, p. $107-$ 126.

REIS, Clayton; SANTOS, Anderson Donizete dos. Responsabilidade civil, as relações de consumo e as diversas formas de publicidade ilícita. Revista Jurídica Cesumar Mestrado, v. 13, n. 2, 2013. Disponível em: < http://periodicos.unicesumar.edu.br/ index.php/revjuridica/article/view/3239/2141> . Acesso em: 26 fev. 2015.

ROPPO, Enzo. O contrato. Coimbra: Almedina, 2009.

SILVA, Rosane Leal da. O direito privado desafiado pela dinâmica da contratação eletrônica: premissas para efetivar a proteção do consumidor brasileiro. In: SEMINÁRIO INTERNACIONAL DEMANDAS SOCIAIS E POLÍTICAS PÚBLICAS NA SOCIEDADE CONTEMPORÂNEA, 11., 2014, Santa Cruz do Sul. Anais... Santa Cruz do Sul: EDUNISC, 2014, v. 1, p. 1-18.

Recebido em: 24 de agosto de 2015 Aceito em: 06 de abril de 2016 